\section{Effects of Single and Fractionated Doses of X-Rays on Mouse Embryos}

That embryonic tissues in vitro may be affected more drastically by fractionated, than by single, doses of X-rays was shown by Spear in $1932^{1}$. Working with chick embryo fibroblasts, he demonstrated that the depression of activity of these cells is far greater with two $2 \frac{1}{2}$-min. exposures separated by $80 \mathrm{~min}$. than with a single 5-min. exposure. In view of the possible significance of these findings for our understanding of the nature of embryonic damage resulting from $\mathrm{X}$-irradiation, and in view of the general interest in the question of radiation hazards to the developing mammalian embryo, the present experiment was designed to determine whether there is a difference between the effects of single and fractionated doses of $\mathrm{X}$-rays on developing mouse embryos in vivo.

Strain-101 female mice were mated to strain- $C 3 H$ males and irradiated with $\mathrm{X}$-rays $(250 \mathrm{kVp} ., 15$ $\mathrm{m}$.amp., $3 \mathrm{~mm}$. aluminium, half-value level $0.4 \mathrm{~mm}$. copper, $80 \mathrm{r} . / \mathrm{min}$.) $9 \frac{1}{2}$ days after the appearance of copulation plugs. Irradiation was administered either as a single dose of $300 \mathrm{r}$. or as three $100 \mathrm{r}$. fractions at 30-min. intervals. Embryos were obtained by dissection three to six days after irradiation. The majority of dissections were made on coded animals. The criteria used were lumbo-sacral spina bifida and coloboma of the eye, two abnormalities which, following irradiation on day $9 \frac{1}{2}$, are produced with high frequency ${ }^{2}$ and are easy to classify accurately by gross inspection. The lumbo-sacral region was scored for length of antero-posterior axis affected; each eye was scored separately for extent of pigment defect.

The two criteria represent strikingly different developmental disturbances. The lumbo-sacral damage consists of a disorientation of the neural tube and somites, resulting in neural arch malformation; the eye defect represents an altered differentiation of optic cup elements, resulting in the presence of retinal sensory cells in areas normally consisting of pigment epithelium (unpublished results).

The results of single and fractionated doses of $\mathrm{X}$-rays are compared in Table 1 . While the incidence of malformation is not affected by fractionation, the severity of embryonic defects is far greater in response to a fractionated dose than in response to a single dose. A striking parallel can be seen between the relative effects of these two methods of irradiation on the lumbo-sacral axis and on eye pigmentation.

It would be premature to speculate on the nature of the processes responsible for the differential effect of single and fractionated irradiation on development.

Table 1. Comparison of the Effects of Single and Fradtionated DOSES OF $\mathrm{X}$-RAYS ON DEVELOPING MOUSE EMBRYOS

\begin{tabular}{|c|c|c|c|c|c|c|c|c|}
\hline & \multicolumn{4}{|c|}{ Lumbo-sacral region } & \multicolumn{4}{|c|}{ Eye pigment formation } \\
\hline & \multicolumn{2}{|c|}{$\begin{array}{l}300 \mathrm{r} . \\
\text { single dose }\end{array}$} & \multicolumn{2}{|c|}{$\begin{array}{l}300 \mathrm{r} . \\
\text { fraction- } \\
\text { ated dose }\end{array}$} & \multicolumn{2}{|c|}{$\begin{array}{l}300 \mathrm{r} . \\
\text { single dose }\end{array}$} & \multicolumn{2}{|c|}{$\begin{array}{l}300 \mathrm{r} \text {. } \\
\text { fraction- } \\
\text { ated dose }\end{array}$} \\
\hline & & $\begin{array}{r}\text { (per } \\
\text { cent) }\end{array}$ & & $\begin{array}{l}\text { (per } \\
\text { cent) }\end{array}$ & & $\begin{array}{l}\text { (per } \\
\text { cent) }\end{array}$ & & $\begin{array}{l}\text { (per } \\
\text { cent) }\end{array}$ \\
\hline $\begin{array}{l}\text { Normal } \\
\text { Mildly }\end{array}$ & & 11.4 & 12 & 15.0 & 33 & $15 \cdot 7$ & 22 & $13 \cdot 8$ \\
\hline $\begin{array}{l}\text { abnormal* } \\
\text { Severely }\end{array}$ & 90 & $85 \cdot 7$ & 17 & $21 \cdot 3$ & 158 & $75 \cdot 2$ & 29 & $18 \cdot 1$ \\
\hline $\begin{array}{l}\text { abnormal } \dagger \\
\text { Total }\end{array}$ & $\begin{array}{r}3 \\
105\end{array}$ & $2 \cdot 9$ & $\begin{array}{l}51 \\
80\end{array}$ & $63 \cdot 8$ & $\begin{array}{r}19 \\
210\end{array}$ & $9 \cdot 0$ & $\begin{array}{l}109 \\
160\end{array}$ & $68 \cdot 1$ \\
\hline
\end{tabular}

- Includes all embryos in which the extent of abnormality (measured in $\mathrm{mm}$. of lumbo-sacral axis and percentage of eye surface) is less than half that found in the most abnormal embryo.

$\dagger$ Includes all embryos in which the extent of abnormality is at least half that found in the most abnormal embryo.
However, from the point of view of developmental mechanies, any interpretation of the nature of embryonic damage in response to $\mathrm{X}$-irradiation must consider the present results, namely, that in the two widely differing embryonic systems so far studied, fractionation is more effective than a single dose, and the degree of increase in effectiveness is similar in the two systems. From the point of view of radiological practice ${ }^{4}$, the demonstration that short-interval fractionation can increase the radiation hazard to developing embryos in vivo adds yet another factor calling for caution.

This work was carried out under contract $W-74.05$ eng-26 for the Atomic Energy Commission.

Biology Division,

Oak Ridge National Laboratory,

Tenn.

Oct. 10

* Present address : National Cancer Institute, Bethesda, Md.

${ }^{1}$ Spear, F. G., Proc. Roy. Soc., B, 110, 224 (1932).

' Russell, L. B., J. Exp. Zool., 114, 545 (1950). Auerbach, R., Anat. Rec., 121, 258 (1955)

${ }^{3}$ Russell, L. B., and Russell, W. L., J. Cell. Comp. Phys., 43, Supp. 1, $103(1954)$

4 Russell, L. B., and Russell, W. L., Radiology, 58, 369 (1952).

\section{A Requirement for Catalase in Tyrosine Metabolism : the Oxidation of p-Hydroxy- phenylpyruvic Acid to Homogentisic Acid}

In this communication evidence is presented that catalase is required in one of the steps of tyrosine metabolism, namely, the conversion of $p$-hydroxy phenylpyruvic acid to homogentisic acid. This oxidation requires two protein fractions which have been separated and partially purified from dog liver by treatment with organic solvents followed by fractionation with ammonium sulphate ${ }^{1}$. Fraction $A$ is precipitated by $0 \cdot 40-0.55$ saturated ammonium sulphate; fraction $B$ by $0.60-0.75$ saturated ammonium sulphate.

In studies to establish the function of the two protein components, it was observed that fraction $A$ contained appreciable amounts of catalase and that the activity of this fraction was proportional to its catalase content. Further experiments showed that fraction $A$ could be replaced by purified catalase obtained from beef or rat liver (Table 1). The product formed from $p$-hydroxyphenylpyruvic acid with fractions $A$ plus $B$ or with catalase plus fraction $B$ was identified as homogentisic acid by chemical analysis and by paper chromatography with methods previously described ${ }^{2}$. Catalase appears to be specifically required in this oxidation, and could not be replaced by ferritin, hæmoglobin or cytochrome $c$.

Various amounts of catalase were added to constant amounts of fraction $B$ (sufficient in the presence of excess catalase to oxidize $5 \mu$ moles of substrate in one hour) to study the effect of catalase on the reaction. When catalase was present in limiting amounts, the rate of reaction, as measured by oxygen uptake, was proportional to the amount of catalase added. $5 \gamma$ of catalase was sufficient to give about one-half the maximal rate and $l_{\gamma}$ produced significant activity. However, at least $30 \gamma$ of catalase was required to give the maximal reaction-rate. The low activity observed when fraction $B$ was tested alone 